\title{
Sustainable Development Under Competing Claims on Land:Three Pathways Between Land-Use Changes, Ecosystem Services and Human Well-Being
}

\author{
Flurina Schneider ${ }^{1}$ (D) - Mélanie Feurer ${ }^{1} \cdot$ Lara Maria Lundsgaard-Hansen $^{1}$. \\ Win Myint ${ }^{2} \cdot$ Cing Don Nuam $^{2} \cdot$ Katharina Nydegger $^{1} \cdot$ Christoph Oberlack $^{1}$. \\ Nwe Nwe Tun ${ }^{2} \cdot$ Julie Gwendolin Zähringer $^{1} \cdot$ Aung Myin Tun $^{2} \cdot$ Peter Messerli $^{1}$
}

Published online: 6 March 2020

(c) The Author(s) 2020

\begin{abstract}
Competition over land is at the core of many sustainable development challenges in Myanmar: villagers, companies, governments, ethnic minority groups, civil society organisations and non-governmental organisations from local to the international level claim access to and decision-making power over the use of land. Therefore, this article investigates the actor interactions influencing land-use changes and their impacts on the supply of ecosystem services and human well-being. We utilise a transdisciplinary mixed-methods approach and the analytical lens of the social-ecological systems framework. Results reveal that the links between land-use changes, ecosystem services and human well-being are multifaceted; For example ecosystem services can decline, while human well-being increases. We explain this finding through three different pathways to impact (changes in the resource systems, the governance systems or the broader social, economic and political context). We conclude with implications of these results for future sustainable land governance.
\end{abstract}

Keywords Claims on land - Sustainability $\cdot$ Ecosystem services $\cdot$ Human wellbeing $\cdot$ Myanmar

\section{Résumé}

La lutte pour la terre est au centre de plusieurs défis de développement durable au Myanmar : les villageois, les compagnies, le gouvernement, les groupes ethniques minoritaires, les organisations de la société civile et non-gouvernementales - du niveau locale au niveau internationale - réclament l'accès à la terre, et le pouvoir de prendre des décisions sur son utilisation. Cette étude enquête les interactions parmi

\section{Flurina Schneider}

flurina.schneider@cde.unibe.ch

1 Centre for Development and Environment (CDE), University of Bern, Bern, Switzerland

2 Environmental Care and Community Security Institution ECCSi, Yangon, Myanmar

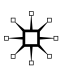


les acteurs qui influencent les changements d'utilisation de la terre, et leur impact sur le bien-être humain et la provision de services d'écosystème. On utilise une approche transdisciplinaire aux méthodes mixtes, et le cadre analytique des systèmes socio-écologiques. Les résultats montrent que les liens entre les changements dans l'utilisation des terres, les services d'écosystème, et le bien-être humain sont polyvalents. Par exemple, les services d'écosystème peuvent baisser et le bien-être humain monter. Nous expliquons cela a travers de trois différentes voies d'impact (changements dans les systèmes des ressources, les systèmes de gouvernance, ou le contexte sociale, économique et politique plus large). On conclut avec les implications de ces résultats pour la future gouvernance durable des terres.

\section{Introduction}

In 2015, the same year that the Myanmar people elected a new civilian government after nearly 60 years of military dictatorship, Myanmar representatives also endorsed the global UN 2030 Agenda for Sustainable Development. The 2030 Agenda constitutes a development vision negotiated by the global community, which is aligned around ' 5 Ps' (people, planet, prosperity, peace and partnership) and 17 sustainable development goals (SDGs) embracing social, environmental and economic dimensions (United Nations 2015). In 2018, sustainability goals and strategies were further specified by the Myanmar government in the Sustainable Development Plan (GoM 2018). However, implementation of these sustainability visions is not an easy task because there are not only synergies but also fundamental tradeoffs between different goals such as conservation of biodiversity (SDG 15) and food security (SDG 2). Different actors usually have quite distinct visions of how these trade-offs should be resolved (Zaehringer et al. 2019).

As the use of land is key for many of these goals, competing claims on land are at the core of many related development disputes (Sachs 2018; Smith 2018; Zaehringer et al. 2019). Villagers, companies, governments, ethnic minority groups, civil society organisations (CSOs) and non-governmental organisations (NGOs) from local to international level compete for access to and decision-making power over the use of land based on different arguments such as livelihoods security, place of belonging, economic assets, habitat for flora and fauna and territorial sovereignty (Franco et al. 2015; Li 2014; Meyfroidt et al. 2018). The fundamental changes in land use and governance occurring in recent years in Myanmar can be seen as the materialisation of the power relationships among the actors involved. Resulting land-use changes include deforestation, establishment of large commercial monoculture plantations (oil palm, rubber, maize), special economic zones and increasing presence of NGOs concerned with the conservation of Myanmar's forests, which belong to the global hot spots of biodiversity (De Alban et al. 2019; Mark 2016; Scurrah et al. 2015; Tarkapaw et al. 2016; Woods 2015).

Hence, whether Myanmar can successfully advance towards the 2030 Agenda will strongly depend on how the multiple and competing claims on land are governed in the future. 
The overall goal of this article is to investigate the links between recent land-use changes and sustainable development outcomes to identify leverage points and priority areas of concern for a more sustainable land governance in Myanmar. In particular, we aim to investigate how actor interactions shape land-use changes and how these changes impact on the supply of ecosystem services and human well-being. Investigation of the transformation from forest and shifting cultivation to protected areas and oil palm and rubber/mixed-crop plantations in Northern Tanintharyi highlights three pathways to impact shaped by the varying involvement of characteristics of the resource systems, the governance systems and the broader social, economic and political context.

\section{Myanmar under Competing Claims on Land and Development Visions}

During the military regime, the Myanmar government followed different socialist, communist and capitalist development visions in succession. It established a highly centralised, regulated and authoritarian state to govern the land. Instruments included agricultural master plans such as the Self-Sufficiency Plans of the 1990s. Granting of large-scale land concessions to protected companies ('cronies') was an important means to boost economic development (Fujita and Okamoto 2006; Gum Ja Htung 2014; Thein et al. 2018; Woods 2011, 2015). Moreover, land concessions were also granted for protected areas to conserve precious forests. However, as many of these government-initiated agricultural and conservation concessions were implemented in ethnic minority areas, they might also have served to extend control over these territories (Gum Ja Htung 2014; Woods 2011, 2019).

The transition to a semi-civilian government after 2011 brought a new focus on peacebuilding and economic development according to liberal principles. This changed development vision resulted in various law and policy reforms, including reformulation of the Farmland Law and the Vacant, Fallow and Virgin Land Management Law in 2012 that introduced land-use rights to attract domestic and international investments in land. As a consequence, a further wave of large-scale land acquisitions for oil palm, rubber and other commercial crops began (Fairhead et al. 2012; Woods 2015).

The land development vision of the former military regime was often in conflict with the interests and visions of ethnic minority groups and local communities. As shown by Franco et al. (2015), local communities-besides economic progressoften stress the importance of personal and community well-being based on subsistence agriculture, maintenance of identities as farmers and connections to ancestors and spirits. Under the military regime, many small-holder farmers lost access to their lands cultivated under customary land-use systems due to the land acquisitions implemented as a consequence of the military's development strategies.

Many of these developments also continued after the transition to the civilian government under the National League for Democracy (NLD) that was elected 2015 (Thein et al. 2018).

Current debates on development in Myanmar are shaped by three competing perspectives of what land-related development visions should be (Franco et al. 2015): 
first, the perspective that prioritises capital-intensive large-scale monoculture agriculture and industry projects based on (neo-)liberal values (Woods 2015); second, the view that labour-intensive and small-scale traditional farming, grazing and forestry practices should be recognised, protected and promoted (LIOH 2015); and third, the perspective that calls for protection and conservation of the rich natural environment including forests, waters and biodiversity (FFI 2019).

The Myanmar Sustainable Development Plan (GoM 2018) tries to address all three perspectives, and unlike previous strategies, it considers collaboration between public entities, the private sector and the civil society as crucial. It includes a section entitled 'Improve land governance and sustainable management of resource-based industries ensuring our natural resources dividend benefits all our people'. In this section, historical mismanagement and opacity of land management are explicitly recognised and considered as widespread causes of Myanmar's underdevelopment and degradation of ecosystems such as forests and mountain areas. The plan also expresses the objective to implement 'a more effective and transparent management regime, which must include continued engagement with affected communities' and seeks to strengthen 'rural households' land tenure, property rights and related enforcement capacities'. However, the overall orientation of the Myanmar Sustainable Development Plan heavily focusses on rapid growth, economic stability and private sector integration. Effective governance and sustainable management of natural resources are introduced primarily as essential means to sustain economic growthpeople's well-being is only mentioned later.

\section{Land Systems, Ecosystem Services and Human Well-Being}

Land system science is at the forefront of research aiming to generate much-needed knowledge that can help to find land-related pathways towards sustainable development (Zaehringer et al. 2019). Land system science considers land as a socialecological system encompassing dynamics and activities related to the human use, as well as its drivers and consequences (Reenberg 2009; Turner et al. 2007; Verburg et al. 2013). To analyse the consequences for sustainable development, land system scientists operationalise sustainability from a perspective of inter- and intra-generational justice and stress the importance of integrating various actor perspectives (in particular of local communities) (Zaehringer et al. 2019). From this perspective, sustainable development of land systems requires that people living today and in the future can lead a good life, while protecting the environment.

The concepts of ecosystem services (ES) and human well-being support this operationalisation. The concept of ES captures the benefits people receive from the environment (Costanza et al. 1997; Daily 1997), including provisioning (e.g. crops and wild plants), regulating and maintenance (e.g. microclimate) and cultural services (e.g. educational values) (Haines-Young and Potschin 2018). Land-use change is often regarded as the main driver for changing ES supply. Human well-being is a multidimensional concept, and various approaches have been suggested for its conceptualisation and analysis. In recent years, a shift occurred from focussing on human well-being in terms of basic needs to a broader conception of well-being in 
terms of capabilities (Alkire 2002; Robeyns 2005). Accordingly, human well-being can be defined as the freedom people have to live a life they value (Abunge et al. 2013).

To capture the link between land-use changes, ES and human well-being, the 'cascade-model' proposed by Haines-Young and Potschin (2010) has become very popular. It conceptualises the link between these elements as a chain of causality from biophysical structures and processes, functions, services, benefits and values. While the model has been substantially adapted in recent years, e.g. by differentiating the causal relations and involving various feedback loops (e.g. Daw et al. 2016), it still strongly assumes a sequential causal relation between the elements mentioned. However, there is increasing evidence indicating that these links between land-use changes, ES and human well-being are more complex and multifaceted (Horcea-Milcu et al. 2016) and that ES cannot simply be equated with people's claims on land. Consequently, land system scientists have increasingly called for more nuanced understandings and for highlighting questions of land governance (Verburg et al. 2015; Zaehringer et al. 2019). Land governance relates to the norms and rules of interaction between different actors involved in land use and the resulting power relationships (Biermann et al. 2009; Graham et al. 2003; Rist et al. 2007). It encompasses land tenure, access to land, land-use decision-making, customary practices and formal and informal policies and laws. The analysis of the actors' agency is seen as particularly important as it can yield insights into who has the power to shape the future of land use (Eakin et al. 2014; Lundsgaard-Hansen et al. 2018; Westley et al. 2013).

However, although land system scientists have started to stress the need for better integration of actors' perspectives, agency and governance questions into research on land systems, there are hardly any frameworks that provide guidance for this endeavour. Indeed, studies investigating the above-mentioned aspects usually focus on individual components of the land system; for example research on land-use changes often fails to consider the actors' agency and power relationships, and studies on land governance generally neglect questions about the ecological potential that certain land uses have to provide ES. This finding also applies to land research in Myanmar. Most studies focus on individual components of the land systems such as oil palm concessions (Nomura et al. 2019), rubber sustainability (KenneyLazar et al. 2018), agricultural expansion (Woods 2015), ocean and land grabbing (Barbesgaard 2019), land cover shifts (De Alban et al. 2019), deforestation (Lim et al. 2017), ecosystem services (Feurer et al. 2019), human well-being (Nydegger 2018), land-use decision-making (Lundsgaard-Hansen et al. 2018) and land-use reforms (Mark 2016), but there are very few studies that link these elements.

In this article, we argue that an integrative perspective is needed to better understand how land-use changes and sustainability outcomes in terms of ES and human well-being are linked. This requires systematic integration of knowledge on land-use system dynamics and actors' agency.

To tackle this knowledge gap, we adopt the social-ecological systems framework (SESF) (Ostrom 2009). The SESF is a template for diagnosing sustainability challenges by investigating explanatory relationships between resource and governance systems linked through focal action situations. The framework has been designed 
to build generalisable statements for theory and policy, while recognising contextual differences between cases (McGinnis and Ostrom 2014). The SESF is one of the most widely adopted approaches to study social-ecological systems. It has been applied to understand social and ecological performance in specific land uses such as forestry and pasture land, but to date it has not been systematically applied to study land-use changes (Partelow 2018). We consider the SESF as a suitable framework for our study as it allows us to combine the systems perspective popular in land system sciences with an actor perspective highlighting actors' agencies and governance. This further enables the integration of insights from various disciplines (Marshall 2015).

To investigate the links between land-use changes, ES and human well-being, we ask two main research questions:

(a) How do actor interactions shape land-use changes?

(b) What is the role of these land-use changes for ES supply and human well-being?

\section{Method}

\section{Conceptual Framework}

As stated above, to address our research questions, we adopted the SESF introduced by Elinor Ostrom and colleagues (Ostrom 2009). At the heart of the SESF are the focal action situations in which actors make decisions and interact with each other and the concerned governance and resource systems. The governance systems define and set rules for the actors, which interact in the action situations. The resource systems involve resource units, which give inputs to the interactions. Sustainability outcomes are regarded as the result of these actor interactions. The focal action situations are embedded in the broader social, economic and political context and related ecosystems (McGinnis and Ostrom 2014; Partelow 2016).

Figure 1 shows how we operationalised the SESF for the study of sustainability outcomes related to land-use changes: Land uses such as forestry, shifting cultivation or commercial plantations are our focal resource systems. The land-use changes represent changes in the resource systems over time. The sustainability outcomes of concern in this study are ES and human well-being. These are seen as characteristics of the resource units and the actors, respectively. ES categories were identified through adapting the Common International Classification of Ecosystem Services (Haines-Young and Potschin 2018) and involve subsistence crops, commercial crops, livestock, wild plants, fuelwood, water flow, biodiversity, microclimate, educational values and cultural identity. Human well-being was understood from the perspective of Nussbaum's capability approach (Nussbaum 2011), covering the dimensions of life expectancy, bodily health, bodily integrity (e.g. free movement, security), senses, imagination and thought (e.g. education), emotions (e.g. family relations), practical reason (e.g. liberty of conscience), affiliation (e.g. non-discrimination, free speech), other species, play and control over one's environment (e.g. property rights, participation in decision-making). 
Social, Economic, and Political Context

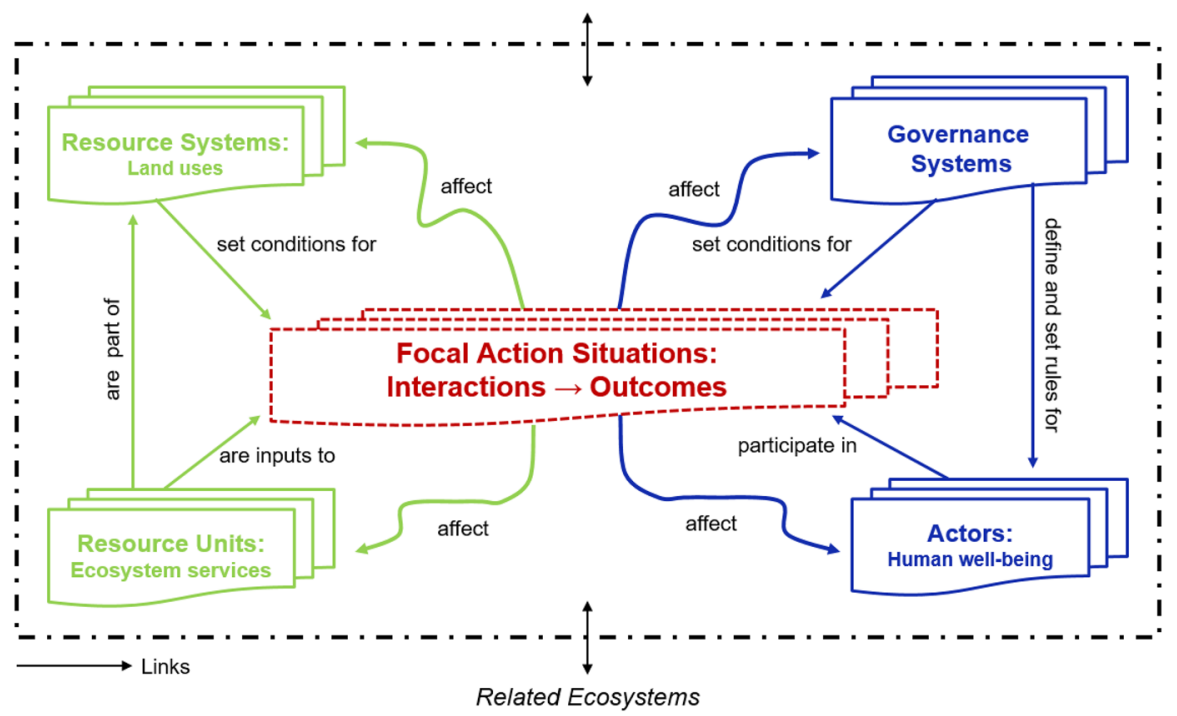

Fig. 1 Revised social-ecological systems framework adapted for the analysis of land-use changes (adapted from McGinnis and Ostrom 2014)

The links between land-use changes and sustainability outcomes in terms of ecosystem services and human well-being are mediated by the actor interactions taking place in the focal action situations. These, in turn, are shaped by the resource and governance systems and the broader context. To consider the temporal dynamics of land-use changes, we trace the actor interactions and their outcomes over the whole time period of the observed changes. By doing so, we distinguish two key phases of different context conditions: the time of the military government and the time after the transition to the new (semi-)civilian government starting in 2011/12 (Cole et al. 2019). ${ }^{1}$

\section{Case Study Region}

The research was conducted in northern Tanintharyi Region, southern Myanmar, in villages located in the surroundings of Tanintharyi Nature Reserve (TNR), the planned Dawei special economic zone (SEZ), the Yadana and Yetagun gas pipelines and the oil palm concessions (Fig. 2). The region was selected as it is a site where multiple actors from local to international level compete for access to land (villagers, companies, governments, ethnic minority groups, CSOs and NGOs).

Both the Myanmar government and the Karen National Union (KNU), the main local ethnic political group, claim sovereignty over parts of these areas and were

\footnotetext{
${ }^{1}$ As we use the framework for the synthesis of a transdisciplinary project, we use the first tier components, but not the second and third tier components defined by the SESF.
} 


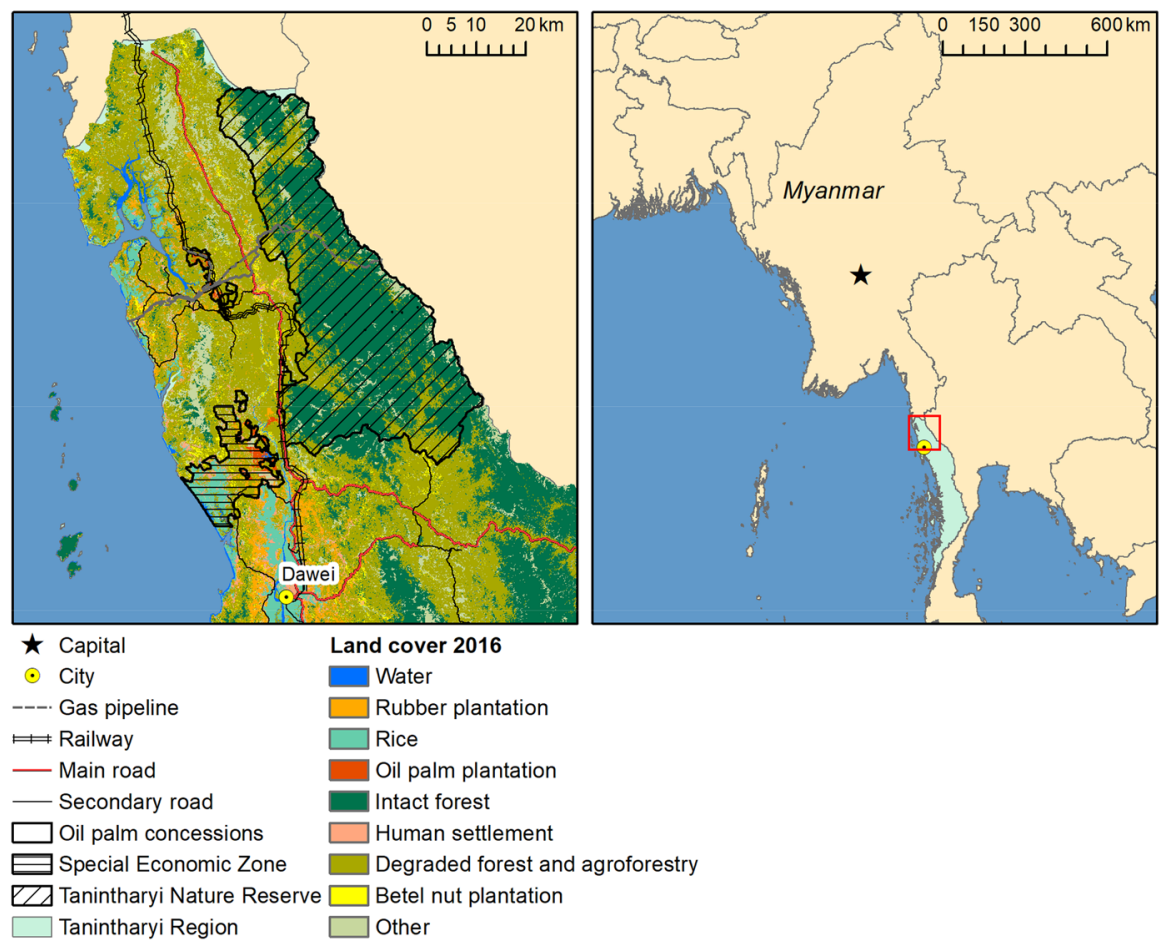

Fig. 2 Overview of study area, northern Tanintharyi Region, Myanmar. Data sources: (Schmid 2018)

involved in armed conflicts until the recent past. Many villages are located in the so-called mixed control area, and almost all villagers were in some way (involuntarily) involved in the civil war. Active fighting was most intense in the 1990s and early 2000s and came to an end with the cease-fire agreement of 2012.

Villagers are mostly farmers, but some also operate smaller businesses. They belong to the Bama, Karen or Mon ethnic groups. Due to the long-lasting civil war and the poor infrastructure, the region became quite isolated and without easy access to markets. Consequently, many villagers migrated to Thailand, although the region also experienced considerable influx of landless immigrants from other regions of Myanmar. At the time of writing, foreigners still need a special permit to visit the villages.

The specific social-ecological system constellation might be unique, considering the great diversity of Myanmar, but the multi-level multi-actor situation is also widespread in many other regions of Myanmar.

\section{Methods}

This research is the result of a synthesis effort of the project Managing Telecoupled Landscapes. The project investigated sustainable landscape management from 
a transdisciplinary perspective (Pohl and Hirsch Hadorn 2007); i.e. researchers from natural and social sciences worked together with societal actors involved in the issue to jointly co-produce new knowledge relevant for more sustainable development. The overall project began with a 1-year inception phase, where we established the Switzerland-Myanmar partnership and jointly framed the key features of the study. It was followed by a 3-year empirical research phase, during which researchers from different disciplines (geography, biology, environmental sciences, economics, agriculture and forestry management) implemented their methods and finally engaged in synthesis activities. The research team involved three senior researchers, two post-docs, three graduate students and four research assistants. The Myanmar senior researcher led the overall project implementation. The Swiss senior researchers and post-docs supervised the different empirical studies and the synthesis endeavour. The post-docs, students and assistants (four of them from Myanmar) designed and implemented the studies. The fieldwork was conducted in tandem by Swiss and Myanmar researchers who worked together closely. Swiss students were partly located in Myanmar (from 3 months to 3 years).

The original research that we synthesised for this article was based on a mixedmethods approach and involved interviews, surveys, focus group discussions, participatory mapping and document review conducted in a series of joint field missions. A first 2-week field mission served to select suitable case study villages, to start collaboration with villagers and to gain an initial understanding of the local situation. In this mission, we also identified the most important land-use changes from the perspectives of the villagers, which were the basis of the following research.

The later missions lasting between 1 week and 3 months were dedicated to the following research themes: land-use changes, ecosystem services, human wellbeing, actors and agency. Land-use changes were further investigated through a combination of high-resolution satellite imagery with participatory mapping workshops and extensive field walks with villagers knowledgeable about the past changes (Zaehringer et al. 2020). Changes in regard to ES and human well-being were analysed through 16 focus groups and 27 expert interviews on ES supply (Feurer et al. 2019), and 6 focus groups and 52 standardised interviews for human well-being (Nydegger 2018). In both cases, the assessment included elements the local villagers considered as important, how they rated the current status/development of these elements and what has influenced change over time. Issues of actor interactions, including governance arrangements, were addressed by all these methods, but in addition, specialised focus groups ( 9 in total), interviews with local villagers, companies, CSOs, NGOs and government representatives (92 in total) and a literature review (grey literature, policies, reports) were conducted (Lundsgaard-Hansen et al. 2018). More details on the methods used for data collection and analysis can be found in the research publications mentioned above.

To integrate the empirical knowledge generated by the different study teams, we used a dialogue method approach. Dialogue methods help structure group conversation processes that aim to 'jointly create meaning and shared understanding about real-world problems by bringing together knowledge from relevant disciplines' (McDonald et al. 2009, p. 5). They highlight conversation criteria such as active listening, equal participation and mutual probing of assumptions (Franco 2006; 
McDonald et al. 2009). Furthermore, the empirical research products were used to substantiate the insights generated.

Hence, a key part of the actual synthesis was elaborated in a 4-day workshop by all researchers involved in the project (except two assistants). First, the researchers presented their key findings using predefined guiding questions related to the SESF components. Second, the three most dominant land-use changes (in terms of area and impact perceived by villagers) were selected based on the results of participatory mapping and focus group discussions and explored in depth. Sub-groups of researchers discussed how the actor interactions and other factors of the resource and governance systems affected the land-use changes, which actors could enforce their claims on land, what outcomes were observed and how they related to each other. The insights were visualised on flip-charts through causal loop diagrams and written down in short texts. The diagrams were then presented to and refined by the whole group. By doing so, knowledge of different participants could be collected and integrated.

After the workshop, the first author further prepared the insights generated according to the SESF and systematically reviewed all existing project outputs (including informal field reports) regarding additional insights that might have been overlooked during the workshop. This analysis was based on procedures of qualitative content analysis (Flick 2005). For each land-use change, she scrutinised the workshop documents and project publications regarding information specifying the SESF key components and their interrelations. To answer the first research question (How do actor interactions shape land-use changes?), she systematised the documented actor interactions, including the actors involved, their claims on land as well as the relevant elements of the governance and resource systems. To answer the second research question (What is the role of these land-use changes for ES supply and human well-being?), she compared the findings from the ES and well-being studies that report on the SESF outcome components resource units and actors. Based on this overview, she identified the key pathways to impact and the roles landuse changes play for ES and well-being. The findings were verified by the whole research team through several feedback rounds.

\section{Results}

This section is structured using the two research questions. Insights from the literature review are cited; all other information is based on our own empirical work.

\section{How Actors' Interactions Shape Land-Use Changes}

In the following, we investigate the action situations related to the three most important land-use changes in terms of impact and spatial extension: (1) implementation of the protected public forest TNR, (2) conversion to oil palm and (3) conversion to rubber and mixed-crop plantations. 


\section{Implementation of the Protected Public Forest TNR}

Implementation of the protected public forest TNR was a contested project, mainly shaped by actor interactions involving the government's forest department, oil and gas companies, the military and the KNU_-all campaigning with different claims on land. Villagers and NGOs became involved only in the later stages.

In 1996, the forest department officially recognised the TNR to conserve a recognised biodiversity hotspot based on the 1992 Forest Law and the 1995 Forest Policy, but they could not formally establish it until security and financial concerns were settled. At the time, the wider area was largely controlled by an ethnic political organisation, the KNU, which claimed sovereignty over the area and disapproved the establishment of the TNR. Forest department staff could only start to implement the protected area once the military gained control and created a 'safe' environment in the conflict area.

However, it is most likely that the military's activities were not primarily aimed at biodiversity conservation, but at control of the land in the region for economic activities and territorial sovereignty (Barbesgaard 2019; Woods 2019). In particular, they protected oil and gas companies (Total, PTT-EP, Petronas), which started to take up business in the region in the 1990s to explore and extract off-shore natural gas for export to Thailand.

Oil and gas company activity was also critical for solving the financial issues. To compensate the Myanmar government for the construction of pipelines crossing the biodiversity-rich forests (right of passage) and to tackle reputational risks- the companies have been accused of collusion in human rights abuse-they agreed to finance the TNR through a public-private partnership based on a voluntary contract (Pollard et al. 2014). According to our interviews, villagers were not involved in the decision to establish the TNR. They were only informed later in the course of the TNR implementation.

The government transition and the cease-fire agreement of 2011/12 influenced the TNR-related focal action situation in two ways. First, the improved security situation allowed the forest department to further implement the TNR rules at the western park boundaries, thereby strengthening the claim for conserving biodiversity. For patrolling the deeper forest, however, the TNR rangers need to coordinate their patrols with the KNU as a matter of respecting the cease-fire agreements, because at the present time, the KNU still holds sole control over large parts of the TNR area including several Karen villages that lie within the protected area. Having their own perspectives on sustainable land management (2015 Land Use Policy), the KNU does not accept the TNR rules defined by the Myanmar government and continues to allow the use of the area for subsistence and commercial crop production. Second, community rights, already formally established in the 1995 Forest Policy, became more widely known and implemented. In 2013, an international NGO aiming to empower local people for community-based sustainable forest management started to support the villagers in applying for community forestry certificates. These certificates allow for communal uses for 30 years, and since a law revision in 2016, also for minor commercial uses. 


\section{Conversion to Oil Palm Plantations}

The conversion from forest, shifting cultivation and perennial plantations of cashew and other crops to oil palm monoculture was mainly driven by the former military government's self-sufficiency policy and palm oil companies' business interests (crony companies and smaller regional companies). It was highly disapproved by other actors such as local villagers and the KNU. Further actors such as the regional government, CSOs and foreign aid providers became relevant in recent years.

The self-sufficiency plan was intended to reduce the country's dependency on imported products and to satisfy the increasing demand of the domestic population for cheap edible oil (Woods 2015). To implement this plan, the government granted oil palm concessions to crony companies. Our research shows that, in most cases, villagers were not involved in the oil palm development and had resentments against the companies. Being extraordinarily poor and heavily affected by still ongoing military oppression, villagers often did not dare to oppose the companies because they were afraid of their relationship with the military. The KNU also strongly disagreed with the oil palm expansion, but they could not stop the development either due to the military's superior power. In some other cases, smaller regional companies or entrepreneurs applied for small- to medium-scale land-use permits to establish an oil palm business of their own accord. In these cases, the companies and local villagers usually respected each other's activities.

The government transition of 2011 brought one new development to the oilpalm-related action situation. In 2016, the Regional Chief Minister created multistakeholder platforms (MSP) that aimed to review the oil palm concessions and to redistribute uncultivated land. The MSP is facilitated by the foreign aid and central government supported OneMap project. The MSP has-for the first time since the outbreak of civil war many decades ago-brought actors from different societal factions to one table: government representatives of various departments, palm oil companies, CSOs, village representatives and the KNU. While concessions have been revoked in a few cases, the multi-stakeholder process is highly challenging due to the multiple claims of the actors involved and currently seems to be blocked. This might also be an indication that the former power relationships still largely persist (for more information see Bächtold et al. in this special issue).

\section{Conversion to Rubber and Mixed-Crop Plantations}

The Myanmar government also played an important role in the conversion to rubber monoculture and mixed-crop plantations (mainly cashew and betel nut but also other crops such as lime or cacao), but in contrast to the other two land-use changes, villagers and smaller regional companies and entrepreneurs from nearby towns also played a key role in and welcomed the conversion.

Once the most severe phases of the civil war with food insecurity, lack of transport and market access, as well as widespread violence had subsided, local communities started to complement their subsistence-oriented farming activities with commercial activities to increase their income and satisfy their livelihoods. But it was only in around 2005/2006 when the Myanmar government pushed the rubber market 
in the context of their 2000-2030 Master Plan for the Agriculture Sector and abolished the government quotas that increasing numbers of villagers and entrepreneurs from nearby towns engaged in the business-until then, $45 \%$ of private harvest was reserved for the government (Woods 2015). Entrepreneurs were attracted due to the great promise of the crop (it was perceived as 'white gold', even though it did not turn out as such later) and the easy access to land. Unlike oil palm, rubber was not regulated through concessions but through different mostly customary land rights and the KNU land policy. Entrepreneurs generally accepted these rights and policies. Some villagers acted as land brokers and unofficially organised the land deals. As a consequence, within only a few years, land turned into a pricey and scarce resource.

The government transition of 2011 fostered a veritable production boom, through which shifting cultivation was mostly abandoned (at least in the government-controlled areas). This was for two reasons: first, the decrease in armed conflicts enabled the villagers to regain mobility as they could access their plots and the market places again due to better security; second, the legal reforms replacing the customary-dominated land tenure system with formal land certificates created a legal land market (Kenney-Lazar et al. 2018; Woods 2015). Land users can obtain land use certificates (e.g. Form 7) if they can prove that they cultivate crops on their land. This encouraged many villagers to convert shifting cultivation systems into permanently cultivated cropland. Moreover, it is likely that entrepreneurs from nearby towns were motivated by rubber not only as a valuable commodity, but also as a land-claiming strategy in the context of land speculation against the background of the announced Dawei special economic zone strongly promoted by the governments of Myanmar and neighbouring countries. Indeed, only a few rubber plantations are professionally managed and none of the actors interviewed had succeeded in producing goodquality rubber or achieved a satisfactory income from rubber.

\section{The Role of Land-Use Changes for ES and Human Well-Being}

\section{ES Supply and Use}

The analysis of local actors' perspectives showed that, compared with the 1990s, when the landscape in northern Tanintharyi was dominated by forest and shifting cultivation, today, the supply of many ES have declined while a few have increased (mainly commercial crops such as rubber, cashew, betel nut and lime). The general decline in the supply of regulating ES such as biodiversity, water flow and regulation of microclimate, as well as a decline in the provisioning of wild plants, fuelwoods and livestock can be explained by an overall loss of intact forest landscapes. Hence, it is directly attributable to the changing resource systems. But in other cases, new rules and regulations have narrowed villagers' access to and use of ES in the remaining forests and also in company-owned oil palm plantations. Thus, the decline in ES supply is not only the consequence of the changing resource systems, but of the changing governance systems too. 
The three land-use changes played different roles for ES supply and use. In the case of the TNR implementation, many regulating ES could be maintained through protecting the forest and vulnerable ecosystems. Forest cover is clearly higher within the TNR than outside, but satellite images also show various signs of logging and crop production activities inside the protected area, pointing to the fact that deforestation could not be stopped completely (Pollard et al. 2014). Provisioning ES related to subsistence use are also often still available, but due to the TNR regulations, they cannot be readily accessed any more by the local communities along the western boundary-with the exception of some community forest areas.

ES trade-offs caused by land-use changes are most pronounced for the conversion of forests to oil palm plantations, as their chemical-intensive management has particularly negative consequences for many regulating ES, such as water flow and biodiversity. Additionally, access to provisioning ES from oil palm plantations, such as firewood and livestock, are socially differentiated. While many villagers do not have access to them due to company regulations, company-related actors such as (mostly migrant) plantation workers do. The only ES that increased is commercial crop production for the companies. But, ironically, despite Tanintharyi Region being the most suitable region for oil palm cultivation within Myanmar, the climate and environmental conditions are not appropriate enough for effective oil palm production and yield. Thus, palm oil companies cannot compete with those in Malaysia and Indonesia. Consequently, the established oil palm plantations are not very profitable and the actually planted areas are often much smaller than the granted concessions.

The conversion from forest to rubber and mixed-crop plantations decreased the overall supply of ES, but it substantially increased the provisioning services of commercial and subsistence crop production. The cultural services also shifted. Having strong connections with nature, local communities attribute many cultural ES to forest ecosystems. But also shifting cultivation is deeply embedded in their culture, and more recently, they started to assign cultural values to rubber and mixed-crop plantations (e.g. betel nut) as they allow them to generate income and acquire a different way of life. Consequently, considering the conversion of forests/shifting cultivation into rubber or mixed-crop plantations, trade-offs between different ES seem almost balanced in the perspectives of local communities. Villagers can obtain more income from commercial crops as a solid and diversified subsistence base (except for rice). Nevertheless, while interviewees generally accepted a slight decrease in biodiversity, climate regulation and cultural services, limited water supply, which is affecting agricultural production and human well-being most directly, was considered at risk if forests in important water catchment areas are cut down.

\section{Human Well-Being}

According to the perspective of the villagers, the human well-being situation has generally improved since the land-use conversions started in the 1990s-but not necessarily to satisfactory levels and not for all people. Elements that improved included, in particular, life expectancy, bodily health including nutrition, bodily integrity including housing and security, options for education, free speech and living together as a family, as well as the capability to control their environment 
through access to land and income opportunities. However, many people still live under adverse conditions and struggle with basic livelihood issues. They also deplored lost access to land, water and forest resources.

The changes in human well-being can partly be explained through the changes in the land-use-related resource systems and ES. For example, deforestation reduced the water flows, which negatively affected crop production and drinking-water quality, which again negatively affected well-being related to human health and nutrition.

In many other cases, however, human well-being dimensions were improved or worsened through changes in the land-use-related governance systems (e.g. new use regulations) or the broader social, economic and political context. In particular, interviewees often highlighted the significance of the ending of the civil war. During the war, where the military and the KNU were fighting for sovereignty over the region to implement their claims on land, people heavily suffered and were deprived of many basic capabilities needed to lead a good life. They regularly had to hide in the forest, plantations were destroyed, public services such as clinics and schools were scarce, and free movement was impossible due to fighting, movement control, lack of infrastructure such as roads and few motorbikes and cars. Human rights violations were also reported. It was particularly challenging for the Karen villages, which suffered heavily from the military's counter-insurgency activities. Hence, once the immediate violence threatening people's lives and bodily integrity stopped, they could take up again basic activities such as accessing and cultivating their fields, visiting relatives and friends and the construction of infrastructure, such as roads, transport and electricity.

Investigation of how well-being was affected by the three land-use changes revealed diverse outcomes. The TNR implementation affected, in particular, villagers at the western park boundaries, as they were officially prohibited to use various forest-based ES. While villagers benefiting from commercial crops could compensate this loss more easily, people not owning land were affected more strongly. When the community forestry rights became more widely known and implemented through the help of an NGO and the TNR management itself, the situation started to improve again (but the community forestry products are still not ready to be harvested).

Conversion to oil palm plantations heavily affected the well-being of the people using these lands. While most concessions of crony companies were granted on land that official records classified as so called 'waste land' or reserved forest land, i.e. land that is officially not used for agricultural activities, interviews revealed that these lands were in fact often claimed by villagers for subsistence and commercial crop production, grazing or collection of wild plants or firewood. Hence, as a consequence of the oil palm concessions, villagers lost their lands and thereby their capability to achieve various land-based well-being dimensions such as nutrition, participation in the community life and control over their environment. Moreover, human rights violations have been reported.

Conversion to rubber and mixed-crop plantations, which were co-driven by the local communities' struggle to generate income opportunities, led to an overall increase in human well-being, despite an overall decrease in ES. While most ES decreased, commercial crop production increased and thereby the villagers' financial 
resources. As a consequence, people could substitute benefits they formerly received from the environment with other products. For example, while forest products such as fuelwood, timber, wild food and medicine became scarcer, people started to use concrete and metal to build their houses, and they were able to buy medicine and food on the market. This might also be the reason why we could not observe extensive negative effects from giving up subsistence rice production: villagers usually obtain enough money from the sale of their commercial crops and have a secured access to markets to buy rice.

Moreover, the increasing rush on land due to all three land-use changes has intensified land scarcity. Consequently, there is a widespread fear among villagers of losing their land or not being able to extend their agricultural fields for new family members due to the general land-rights insecurity. As work and income opportunities of local communities are still strongly based on agricultural activities, not owning land is a major challenge and affects many well-being dimensions.

\section{Discussion and Conclusion}

Our research aims to explore the link between recent land-use changes and sustainable development in Myanmar through an interdisciplinary synthesis effort. In particular, we investigated how actors' interactions shaped land-use changes and the role of these land-use changes in ES supply and human well-being in northern Tanintharyi. The generated results contribute to ongoing wider developments of middlerange theories in land system science (Meyfroidt et al. 2018), as well as to identify pathways for more sustainable development in Myanmar.

\section{Contributions to Middle-Range Theories Linking Land-Use Changes, ES and Human Well-Being}

Adopting the SESF as an analytic lens to study how land-use changes translate into ES and human well-being, we found that, until the 1990s, the action situations around land in northern Tanintharyi were shaped by local villagers and their ethnic organisations, who claimed the forested land for subsistence use and maintenance of their livelihoods and identities, mostly in shifting cultivation systems. Since then, increasing numbers of other actors from regional to international level have entered the action situations (different entities of the central and regional government, companies, NGOs and CSOs), leading to three main land-use changes: (1) implementation of the protected public forest TNR, (2) conversion to oil palm, and (3) conversion to rubber and mixed-crop plantations. Shifting cultivation for subsistence rice production has been widely abandoned, and larger areas of intact forest can only be found in the TNR and along the border with Thailand. These results confirm findings of other recent land-use-change studies in Myanmar (De Alban et al. 2019; Lim et al. 2017; Woods 2015). 
The land-use changes investigated were driven by different actor constellations. Their claims on land were shaped by heterogeneous commercial, conservation and political interests. Depending on the actors' agencies and prevailing power relations, some actors were more successful than others in implementing their claims. While local communities played an active role in the conversion to rubber and mixed-crop plantations, decisions on the two other changes-implementation of the protected area TNR and conversion to oil palm plantations-were mainly taken by powerful actors at places and scales beyond the local systems (in particular, national and international companies and the former military government), making it difficult for villagers to realise their own development aspirations.

But consequences for ES and their link to human well-being are complex and multifaceted. While the three land-use changes resulted in a decline of many ES, in particular regulating services such as biodiversity and water flow, overall, human well-being improved for many people - though not for all.

Hence, our empirical research challenges models that relate land-use changes, ES and human well-being in a linear way, in particular, the widespread belief that deforestation will lead to a decline in the well-being of people due to a decline in ES supply (Raudsepp-Hearne et al. 2010). In contrast, we found that multiple ways exist to explain the relation between land-use changes, ES and human well-being.

Referring to the SESF, they can be divided into three different pathways to impact. The interactions between specific actors are key in all of them, but depending on the action situation, the characteristics of the resource systems, the governance systems or the broader social, economic and political context are decisive for their outcomes. For example, deforestation leading to a decrease in ES supply of wild plants and livestock, which in turn decreases human well-being of dependent villagers, can be understood as a change in the resource system leading to a change in the resource units (ES) involved, which in turn negatively effects the well-being of certain actors.

However, whether this change effectively translates into negative well-being impacts depends on the agency of the actors involved and the ruling governance system. In general, we observed that positive well-being effects were more likely in cases where villagers could co-drive the land-use change and thereby enforce their own claims on land. For example, deforestation for mixed-crop plantations often decreased overall ES supply but increased commercial crops. As a consequence, villagers having use rights for these lands can substitute benefits they formerly received from the forest with other products. This decoupling of ES and human well-being is a trend that has often been observed in countries of the Global North (HorceaMilcu et al. 2016), but also seems to be relevant for countries of the Global South (Urech et al. 2015). People tend to adjust valuations of some services over time. Valuations of ES are changing with the peoples' changing needs, expectations and interactions with nature. Thus, future research on the link between land-use changes, ES and human well-being must reflect on a more constructivist and less positivist logic (Raudsepp-Hearne et al. 2010; Urech et al. 2015).

Moreover, in many cases, it is not the land-use changes and related ES that influence human well-being, but the broader socio-political processes involved in the land-use competition. Indeed, the termination of the active fighting between 
the Myanmar military and the KNU and the activities of the oil and gas companies might be the main reasons for the increased well-being of the local communities. The peace agreement ended more than six decades of civil war that undermined human well-being, and it created favourable conditions for local communities to engage in agriculture or other economic development. The complex ways armed conflicts can influence land-use changes and human well-being have also been raised by Baumann and Kuemmerle (2016), but despite the significance of the topic, it represents an underexplored topic in land system science.

\section{Implications for Sustainable Development}

Since the government transition starting in 2011/12, several windows of opportunities emerged in northern Tanintharyi Region, in particular allowing people to re-engage in economic and political activities, lead a life in peace and furthermore increase their well-being. However, current social, economic and political developments dominated by market liberalisation and the opaque power situations in place including the unclear role of the military today, also raise questions regarding future sustainable development. It currently seems that economic claims on land and interests of national and international investors are clearly valued more highly than local villagers' interests and customary rights on land (Franco et al. 2015; KHRG 2018; Mark 2016). This is reflected in the recent 2018 revision of the controversial Vacant, Fallow and Virgin Land Management Law, where the opportunity to strengthen community land rights was overlooked in favour of an strengthened process of market liberalisation (41 INGOs and CSOs 2018), and in the stagnating palm oil concession redistribution process (Bächtold et al. same special issue).

Moreover, considering the projected continued deforestation rates and the related decline in ES, it is unclear whether and to what level human well-being can continue to improve in the future, in particular as regulating services such as water flows and biodiversity are much less likely to be substituted (Raudsepp-Hearne et al. 2010). This is relevant in particular because land is becoming increasingly scarce.

Fostering land-use management that is favourable for the well-being of local communities and maintenance of ES in the long term-a precondition for implementing the 2030 Agenda as well as the Myanmar Sustainable Development Planis a truly challenging task. Our findings related to the three pathways to impact point to four priority areas of concern:

- Considering the key role the armed conflict between the Myanmar government and the KNU played in land-use changes, sustained peace might be the single most important factor enabling local communities to enhance human well-being. Moreover, to protect ES in the whole region-inside and outside of the TNRenhanced peace dialogues between the Myanmar government and the KNU must include land-use issues. But sustained peace in itself might not stop ongoing deforestation processes.

- Therefore, strong land-governance arrangements need to be negotiated, simultaneously strengthening ES proliferation and human well-being. These can include 
measures that foster ES and human well-being in the same areas, e.g. community forestry or sustainable mixed-crop plantations, but might also include measures that fully protect intact forests in certain areas, while fostering profitable commercial crop production in others, e.g. professionalisation of rubber production. Moreover, to reduce livelihood dependency on land, the creation of alternative, not-land related or exploiting income opportunities must be developed.

- But today, peoples' livelihoods still strongly depend on land, so securing local communities' access to land is key. Land insecurity also increases the risk of deforestation (Robinson et al. 2014). However, land titling is no panacea. It might also cement existing or produce new inequalities, rendering the villagers even more vulnerable, because — in times of crisis - they might sell their land for short-term money, having less land afterwards (Dwyer 2015).

- However, negotiation and implementation of more promising land-governance arrangements also require broader transformations, namely regarding government accountability and know-how, hidden power relationships between dominant actors from businesses, government and other powerful actors such as the military, as well as widespread societal phenomena related to established fear, mistrust and prejudices towards other actors and ethnic groups.

In short, taking into account the three pathways to impact between land-use changes, ES and human well-being, we argue that future research should deepen the understanding of actors' agencies and power relationships related to land-use changes, including the role of the armed conflict (Woods 2019). Moreover, more emphasis should be placed on what practices and leverage points might effectively foster fundamental transformations of the current social-ecological systems towards more sustainable development.

Acknowledgements We acknowledge support from the Swiss Programme for Research on Global Issues for Development (r4d programme) funded by the Swiss National Science Foundation (SNSF) and the Swiss Agency for Development and Cooperation (SDC) (Grant No. 152167). We thank all regional authorities in the Tanintharyi Region, the township authorities, the village leaders, the villagers, the companies and all other interview partners for their support throughout the fieldwork. We would also like to thank Vicki Harley for copy-editing the manuscript and the anonymous reviewers and the editors for their very constructive comments.

\section{Compliance with Ethical Standards}

Conflict of Interest All authors declare that they have no competing interests.

Open Access This article is licensed under a Creative Commons Attribution 4.0 International License, which permits use, sharing, adaptation, distribution and reproduction in any medium or format, as long as you give appropriate credit to the original author(s) and the source, provide a link to the Creative Commons licence, and indicate if changes were made. The images or other third party material in this article are included in the article's Creative Commons licence, unless indicated otherwise in a credit line to the material. If material is not included in the article's Creative Commons licence and your intended use is not permitted by statutory regulation or exceeds the permitted use, you will need to obtain permission directly from the copyright holder. To view a copy of this licence, visit http://creativecommons.org/licen ses/by/4.0/. 


\section{References}

Abunge, C., S. Coulthard, and T.M. Daw. 2013. Connecting marine ecosystem services to human wellbeing: Insights from participatory well-being assessment in Kenya. Ambio 42: 1010-1021.

Alkire, S. 2002. Dimensions of human development. World Development 30: 181-205.

Barbesgaard, M. 2019. Ocean and land control-grabbing: The political economy of landscape transformation in Northern Tanintharyi, Myanmar. Journal of Rural Studies 69: 195-203.

Baumann, M., and T. Kuemmerle. 2016. The impacts of warfare and armed conflict on land systems. Journal of Land Use Science 11: 672-688.

Biermann, F., M.M. Betsill, J. Gupta, N. Kanie, L. Lebel, D. Liverman, H. Schroeder, and B. Siebenhüner. 2009. Earth system governance: People, places and the planet. Science and implementation plan of the earth system governance project. IHDP: The Earth System Governance Project.

Cole, D., G. Epstein, and M. McGinnis. 2019. The utility of combining the IAD and SES frameworks. International Journal of the Commons 13: 244-275.

Costanza, R., R. d'Arge, R. de Groot, S. Farber, M. Grasso, B. Hannon, K. Limburg, S. Naeem, R.V. O'Neill, J. Paruelo, et al. 1997. The value of the world's ecosystem services and natural capital. Nature 387: 253-260.

Daily, G.C. 1997. Nature's services: Societal dependence on natural ecosystems. Washington DC: Island Press.

Daw, T.M., C.C. Hicks, K. Brown, T. Chaigneau, F.A. Januchowski-Hartley, W.W.L. Cheung, S. Rosendo, B. Crona, S. Coulthard, C. Sandbrook, et al. 2016. Elasticity in ecosystem services: Exploring the variable relationship between ecosystems and human well-being. Ecology and Society 21

De Alban, J.D.T., G.W. Prescott, K.M. Woods, J. Jamaludin, K.T. Latt, C.L. Lim, A.C. Maung, and E.L. Webb. 2019. Integrating analytical frameworks to investigate land-cover regime shifts in dynamic landscapes. Sustainability 11: 1139.

Dwyer, M.B. 2015. The formalization fix? Land titling, land concessions and the politics of spatial transparency in Cambodia. The Journal of Peasant Studies 42: 903-928.

Eakin, H., R. DeFries, S. Kerr, E.F. Lambin, J. Liu, P. Marcotullio, P. Messerli, A. Reenberg, X. Rueda, S. Swaffield, et al. 2014. Significance of telecoupling for exploration of land-use change. In Rethinking global land use in an urban Era, ed. K.C. Seto and A. Reenberg, 141-161. Cambridge: MIT Press.

Fairhead, J., M. Leach, and I. Scoones. 2012. Green grabbing: A new appropriation of nature? The Journal of Peasant Studies 39: 237-261.

Feurer, M., A. Heinimann, F. Schneider, C. Jurt, W. Myint, and J.G. Zaehringer. 2019. Local perspectives on ecosystem service trade-offs in a forest frontier landscape in Myanmar. Land 8: 45.

FFI. 2019. 'Ridge to reef' conservation in Tanintharyi. Cambridge: Fauna \& Flora International.

Flick, U. 2005. Qualitative Sozialforschung: Eine Einführung. Reinbek bei Hamburg: Rowohlt Taschenbuch Verlag.

Franco, L. 2006. Forms of conversation and problem structuring methods: A conceptual development. Journal of the Operational Research Society 57: 813-821.

Franco, J., H. Twomey, K.K. Ju, P. Vervest, and T. Kramer. 2015. The meaning of land in Myanmar. A primer. Amsterdam: Transnational Institute.

Fujita, K., and I. Okamoto. 2006. Agricultural policies and development of Myanmar's agricultural sector: An overview. IDE Discussion Paper 63: 48.

GoM (2018). Myanmar sustainable development plan (2018-2030).

Graham, J., B. Amos, and T.W. Plumptre. 2003. Governance principles for protected areas in the 21st century. Ottawa: Institute on Governance.

Gum Ja Htung, L. 2014. Land grabbing as a process of state-building in Kachin Areas, North Shan State, 1-16. Thailand: Myanmar. Chiang Mai University Press.

Haines-Young, R., and M. Potschin. 2010. The links between biodiversity, ecosystem services and human well-being. In Ecosystem ecology. A new synthesis, ed. David G. Raffaelli and Christopher L.J. Frid, 110-139. Cambridge: Cambridge University Press.

Haines-Young, R., and M. Potschin. 2018. Common International Classification of Ecosystem Services (CICES) V5.1 and guidance on the application of the revised structure.

Horcea-Milcu, A.-I., J. Leventon, J. Hanspach, and J. Fischer. 2016. Disaggregated contributions of ecosystem services to human well-being: A case study from Eastern Europe. Regional Environmental Change 16: 1779-1791. 
INGOs and CSOs. 2018. Letter of concern regarding implementation of the Vacant, Fallow and Virgin Lands Management Law (2012).

Kenney-Lazar, M., G. Wong, H. Baral, and A.J.M. Russell. 2018. Greening rubber? Political ecologies of plantation sustainability in Laos and Myanmar. Geoforum 92: 96-105.

KHRG. 2018. Development without us: Village Agency and Land Confiscations in Southeast Myanmar (Written and published by Karen Human Rights Group (KHRG). www.khrg.org. Accessed 7 May 2019).

Li, T.M. 2014. What is land? Assembling a resource for global investment. Transactions of the Institute of British Geographers 39: 589-602.

Lim, C.L., G.W. Prescott, J.D.T.D. Alban, A.D. Ziegler, and E.L. Webb. 2017. Untangling the proximate causes and underlying drivers of deforestation and forest degradation in Myanmar. Conservation Biology 31: 1362-1372.

LIOH. 2015. Destroying peoples's lives: The impact of land grabbing on communities in Myanmar.

Lundsgaard-Hansen, L., F. Schneider, J. Zaehringer, C. Oberlack, W. Myint, and P. Messerli. 2018. Whose agency counts in land use decision-making in Myanmar? A comparative analysis of three cases in Tanintharyi Region. Sustainability 10: 3823.

Mark, S. 2016. Are the odds of justice "stacked" against them? Challenges and opportunities for securing land claims by smallholder farmers in Myanmar. Critical Asian Studies 48: 443-460.

Marshall, G.R. 2015. A social-ecological systems framework for food systems research: Accommodating transformation systems and their products. International Journal of the Commons 9: 881-908.

McDonald, D., G. Bammer, and P. Deane. 2009. Research integration using dialogue methods (Canberra ACT 0200, Australia: ANU E Press).

McGinnis, M., and E. Ostrom. 2014. Social-ecological system framework: Initial changes and continuing challenges. Ecology and Society 19.

Meyfroidt, P., R. Roy Chowdhury, A. de Bremond, E.C. Ellis, K.-H. Erb, T. Filatova, R.D. Garrett, J.M. Grove, A. Heinimann, T. Kuemmerle, et al. 2018. Middle-range theories of land system change. Global Environmental Change 53: 52-67.

Nomura, K., E.T.A. Mitchard, G. Patenaude, J. Bastide, P. Oswald, and T. Nwe. 2019. Oil palm concessions in southern Myanmar consist mostly of unconverted forest. Sci Rep 9: 1-9.

Nussbaum, M.C. 2011. Creating capabilities: The human development approach. Cambridge, MA: Belknap Press of Harvard University Press.

Nydegger, K. (2018). A wellbeing study in Tanintharyi, Southern Myanmar. Master thesis. University of Bern.

Ostrom, E. 2009. A general framework for analyzing sustainability of social-ecological systems. Science 325: 419-422.

Partelow, S. 2016. Coevolving Ostrom's social-ecological systems (SES) framework and sustainability science: Four key co-benefits. Sustainability Science 11: 399-410.

Partelow, S. 2018. A review of the social-ecological systems framework: Applications, methods, modifications, and challenges. Ecology and Society 23.

Pohl, C., and G. Hirsch Hadorn. 2007. Principles for designing transdisciplinary research. Munich: Oekom.

Pollard, E., Soe Win Hlaing, and J. Pilgrim. 2014. Review of the Tanintharyi nature reserve project as a conservation model in Myanmar. Cambridge: The Biodiversity Consultancy Ltd.

Raudsepp-Hearne, C., G.D. Peterson, M. Tengö, E.M. Bennett, T. Holland, K. Benessaiah, G.K. MacDonald, and L. Pfeifer. 2010. Untangling the environmentalist's Paradox: Why is human wellbeing increasing as ecosystem services degrade? BioScience 60: 576-589.

Reenberg, A. 2009. Land system science: Handling complex series of natural and socio-economic processes. Journal of Land Use Science 4: 1-4.

Rist, S., M. Chidambaranathan, C. Escobar, U. Wiesmann, and A. Zimmermann. 2007. Moving from sustainable management to sustainable governance of natural resources: The role of social learning processes in rural India, Bolivia and Mali. Journal of Rural Studies 23: 23-37.

Robeyns, I. 2005. The capability approach: A theoretical survey. Journal of Human Development 6: 93-117.

Robinson, B.E., M.B. Holland, and L. Naughton-Treves. 2014. Does secure land tenure save forests? A meta-analysis of the relationship between land tenure and tropical deforestation. Global Environmental Change 29: 281-293.

Sachs, J. 2018. Land and the SDGs I Land Portal I Securing Land Rights Through Open Data. 
Schmid, M. 2018. Mapping changes of land systems from 2002 to 2016 in Tanintharyi region, Myanmar. An application of the landscape mosaic approach. Master Thesis. Universität Bern.

Scurrah, N., P. Hirsch, and K. Woods. 2015. The political economy of land governance in Myanmar (Mekong Region Land Governance Project).

Smith, P. 2018. Managing the global land resource. Proceedings of the Royal Society B: Biological Sciences 285: 20172798.

Tarkapaw, TRIP NET, Southern Youth, Candle Light, Khaing Myae Thitsar, Myeik Lawyer Network, and Dawei Development Association. 2016. Green Desert. Communities in Tanintharyi renounce the MSPP Oil Palm Concession.

Thein, U.S., J.-C. Diepart, U.H. Moe, and C. Allaverdian. 2018. Large-scale land acquisitions for agricultural development in Myanmar: A review of past and current processes. Vientiane: Mekong Region Land Governance.

Turner, B., E.F. Lambin, and A. Reenberg. 2007. The emergence of land change science for global environmental change and sustainability. PNAS 104: 20666-20671.

United Nations. 2015. Transforming our world: the 2030 agenda for sustainable development. A/ RES/70/1. https://Sustainabledevelopment.Un.Org/Post2015/Transformingourworld (Accessed at 26.1.2018).

Urech, Z.L., J.G. Zaehringer, O. Rickenbach, J.-P. Sorg, and H.R. Felber. 2015. Understanding deforestation and forest fragmentation from a livelihood perspective. Madagascar Conservation \& Development 10: 67-76.

Verburg, P.H., N. Crossman, E.C. Ellis, A. Heinimann, P. Hostert, O. Mertz, H. Nagendra, T. Sikor, K.-H. Erb, N. Golubiewski, et al. 2015. Land system science and sustainable development of the earth system: A global land project perspective. Anthropocene 12: 29-41.

Verburg, P.H., K.-H. Erb, O. Mertz, and G. Espindola. 2013. Land system science: Between global challenges and local realities. Current Opinion in Environmental Sustainability 5: 433-437.

Westley, F.R., Tjornbo, O., Schultz, L., Olsson, P., Folke, C., Crona, B., and Bodin, Ö. 2013. A theory of transformative agency in linked social-ecological systems. Ecology and Society 18.

Woods, K. 2011. Ceasefire capitalism: Military-private partnerships, resource concessions and militarystate building in the Burma-China borderlands. The Journal of Peasant Studies 38: 747-770.

Woods, K. (2015). Commercial agriculture expansion in Myanmar: Links to deforestation, conversion timber, and land conflicts (Forest Trends and UKaid).

Woods, K.M. 2019. Green territoriality: Conservation as state territorialization in a resource frontier. Human Ecology 47: 217-232.

Zaehringer, J.G., L. Lundsgaard-Hansen, T.T. Thein, J.C. Llopis, N.N. Tun, W. Myint, and F. Schneider. 2020. The cash crop boom in southern Myanmar: Tracing land use regime shifts through participatory mapping. Ecosystems and People 16: 36-49.

Zaehringer, J.G., F. Schneider, A. Heinimann, and P. Messerli. 2019. Co-producing knowledge for sustainable development in telecoupled land systems. In Telecoupling: Exploring land-use change in a globalised world, ed. C. Friis and J.Ø. Nielsen, 357-381. Cham: Springer.

Publisher's Note Springer Nature remains neutral with regard to jurisdictional claims in published maps and institutional affiliations. 